\title{
Extended Technology Acceptance Model for SPSS Acceptance among Slovenian Students of Social Sciences
}

\author{
Alenka Brezavšček, Petra Šparl, Anja Žnidaršič
}

University of Maribor, Faculty of Organizational Sciences, Kidričeva cesta 55a, 4000 Kranj, Slovenia, alenka.brezavscek@fov.uni-mb.si, petra.sparl@fov.uni-mb.si, anja.znidarsic@fov.uni-mb.si

Background and Purpose - IBM SPSS Statistics is among the most widely used programs for statistical analysis in social sciences. Due to many practical values it is frequently used as a tool for teaching statistical concepts in many social science university programs. In our opinion, motivation to learn and to use SPSS during the studying process plays a significant role in building a positive attitude towards SPSS which influences its usage at the professional level after finishing study.

Design/Methodology/Approach - The aim of this paper is the development of the model for analysing the acceptance of the SPSS among university students of social sciences. The model is based on the widely known Technology Acceptance Model (TAM). In addition to the traditional components of the TAM, six external variables were included. The model is tested using the web survey on the university students of social sciences from seven faculties at three Slovenian universities.

Results - The evaluation of the questionnaire was performed. Descriptive statistics were calculated. The dependencies among the model components were studied and the significant dependencies were pointed out.

Conclusion - The results of the empirical study prove that all external variables considered in the model are relevant, and directly influence both key components of the traditional TAM, "Perceived Usefulness « and "Perceived Ease of Use «. Therefore, our model is useful to study the adoption and continuous utilization of SPSS among the students of social sciences. The obtained results are useful for educators, and can help them to improve the learning process.

Keywords: university education, statistics, statistics anxiety, SPSS, acceptance, TAM model

\section{Introduction}

Courses in statistics are important to all business majors because they represent the formal exposure to statistical analyses and research methods which many students may find useful in their careers. Analytical skills enhance students' ability to read, interpret, synthesize and use reported results. On the other hand, research production skills enable students to design and initiate original research (Ravid and Leon, 1995). However, students' personal experiences toward statistics are often a source of anxiety producing negative perceptions. Many researchers have indicated that courses in statistics are among those that cause the most anxiety, especially for students in non-mathematicsoriented disciplines (e.g. Zeidner, 1991; Baloğlu, 2003; Onwuegbuzie, 2004; Pan and Tang, 2004, DeVaney, 2010). Statistics anxiety is experienced by as many as $80 \%$ of graduate students in the social and behavioural sciences and is at least partly responsible for the procrastination of stu-

Received: $6^{\text {th }}$ October 2013; revised: $27^{\text {th }}$ November 2013; accepted $25^{\text {th }}$ January 2014 
dents enrolling in required statistics courses (Onwuegbuzie and Wilson, 2003). Our several years teaching experiences at higher education courses prove that the situation at the Slovenian universities seems to be quite similar. We think that students' motivation for learning statistics and using statistical software is not at a desirable level.

The development and psychometric properties of statistics anxiety scales and the factors affecting statistics anxiety have been extensively studied for more than twenty years, but few studies focused on how to reduce the statistics anxiety for graduate students in the social sciences. A comprehensive summary of the literature on statistics anxiety is provided by Onwuegbuzie and Wilson (2003).

The results of some previous studies indicate that using computers in a statistics class has been generally successful in lowering the statistical anxiety (Stickels and Dobbs, 2007). Among the most widely used programs for statistical analysis in social science is IBM SPSS Statistics. Integration of SPSS into higher education courses in statistics can have many positive effects such as (IBM, 2010):

- Focuses students' attention on learning concepts rather than on formula manipulation.

- Enables teaching of real-life problems, engaging students more actively in the learning process.

- Increases students' confidence in being able to learn and understand what they initially anticipated as being a complicated and difficult subject.

Due to many practical values SPSS is frequently used as a tool for teaching statistical concepts in a majority of social science programs at Slovenian universities.

In our opinion, the motivation to learn and the use of SPSS during the studying process plays a significant role in building a positive attitude towards SPSS and to statistics itself which influences the usage of SPSS at the professional level after finishing the study. The aim of this research is to 1. identify the external factors which may influence the adoption and continuous utilization of the statistical package SPSS among the university students of social sciences;
2. examine the direct and indirect influences of selected external variables on students' behavioural intention which directly affect their actual use of SPSS in the future.

For this purpose a research model, based on Technology Acceptance Model (TAM) will be developed. The model will be tested on university students of social sciences from seven different faculties at three Slovenian universities.

\section{Technology Acceptance Model - TAM}

Technology Acceptance Model (TAM) is one of the most widely used conceptual models in explaining and predicting the adoption behaviour of information technology (Hsu et al., 2009). TAM is widely known and it has received strong theoretical and empirical support in literature, having been cited more than 700 times (Padilla-Meléndez et al. 2013). It was developed by Davis $(1986,1989)$ to explain the nature and determinants of computer usage. The principal scheme of the original TAM is shown in Figure 1.

The original TAM postulates that »Perceived Usefulness « and »Perceived Ease of Use« are key constructs in determining users' acceptance of technology. As articulated by Davis et al. (1989) these constructs are defined in the following way:

- »Perceived Usefulness« is referred to as »the degree to which a person believes that using a particular system would enhance his/her job performance«.

- »Perceived Ease of Use« is referred to »the degree to which a person believes that using a particular system would be free of effort $\ll$.

Both, »Perceived Usefulness « and »Perceived Ease of Use « have influence on »Behavioural Intention to Use«. The user of IS/IT intends to use technology if the user feels the technology will be useful for them and they feel it is easy to use. Despite that, »Perceived Ease of Use« also influences

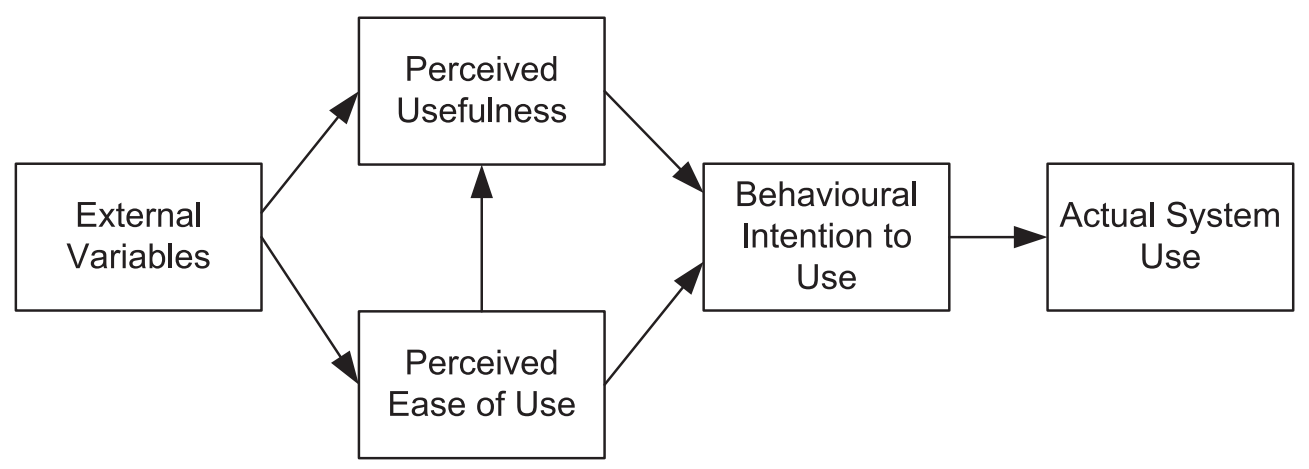

Figure 1: The principal scheme of the original TAM 
»Perceived Usefulness« but not vice versa. Therefore, in TAM applications three conventional relationships are usually formulated in the following research hypothesis (Lee and Letho, 2013):

- $\quad$ Perceived Usefulness« positively affects »Behavioural Intention to Use«.

- $\quad » P e r c e i v e d$ Ease of Use« positively affects »Behavioural Intention to Use«.

- $\quad » P e r c e i v e d$ Ease of Use« positively affects »Perceived Usefulness«.

»Perceived Usefulness « and »Perceived Ease of Use« could be influenced by several external variables which may affect attitudes toward using the system (e.g., documentation, system feature, training, user support, etc.). There are many external variables which are used with practical applications of TAM. Yousafzai et al. (2007) divided them into four categories of organizational, system, users' personal characteristics, and other variables.

The TAM has been validated over a wide range of systems and has been identified as a useful model in a relatively large number of applications over the past two decades. A comprehensive overview of the TAM can be found in Legris et al. (2003) and Chuttur (2009). Some interesting applications in system dynamics can be found in Kljajić et al. (2012) and Wang and Liu (2005).

In recent years several papers have been published on the context of application of TAM in higher education (e.g. Teo, 2009, 2010, 2011a, 2011b). A number of studies have used TAM to examine learners' willingness to accept e-learning systems (e.g., Al-Adwan et al., 2013; Shah et al., 2013; Sharma and Chandel, 2013; Shroff et al., 2011; Tabak and Nguyen, 2013) or to predict learners' intentions to use an online learning community (Liu et al., 2010). Some papers are focused to validate TAM on some specific software which is applied in higher education. For example, Escobar-Rodriguez and Monge-Lozano (2012) use TAM for explaining or predicting university students' acceptance of Moodle platform, while Hsu et al. (2009) performed an empirical study to analyze the adoption of statistical software among online MBA students in Taiwan.

\section{Research model and hypothesis}

The main goal of the paper is to identify the influential factors (the TAM external variables) that may facilitate or hamper the adoption of the commercial statistical package SPSS among the university students of social sciences. The basis for our study represents the empirical study of Hsu et al. (2009). The authors developed an extended TAM including three external variables which are considered also in our model. These variables are:

- „SPSS Self Efficacy« - it can be defined as the belief that one has the capability to perform a statistical analysis using SPSS. Individuals who have high SPSS self efficacy are more likely to use SPSS and would feel a higher level of mastery over SPSS applications.

- "Computer Attitude - it can be defined as an index of the degree to which a person likes or dislikes about computers. A number of empirical studies have found significant relationships between attitudes about computers and usage of them (Hsu et.al, 2009). It is postulated in our model that computer attitude affects the perceived usefulness and the perceived ease of use of SPSS, which in turn, affects the intention of using SPSS in the future.

- »Statistics Anxiety « - it refers to the feeling of anxiety experienced by those taking a statistics course or undertaken statistical analyses. It consists of six dimensions: worth of statistics, interpretation anxiety, test and call anxiety, computational self-concept, fear of asking for help, and fear of statistics teacher. Worth of statistics refers to students' perceptions of relevance and usefulness of statistics, and is a key source of statistics anxiety (Hsu et.al., 2009). It is hypothesized that lower level of statistics anxiety increases the level of perceived usefulness as well as the level of perceived ease of use. Therefore, such students are likely to be more comfortable using SPSS in class and later in their daily jobs.

The model of Hsu et al. (2009) was tested on online MBA students, where many of them are full time employees. However, the results were not compared to students who completed a traditional in class course. Since the online MBA students appear to be more capable, savvy and demanding than traditional students (Bisoux, 2002), it is our opinion that the model for traditional students needs some adjustment. Therefore, we supplemented the model of Hsu et al. (2009) by involving the following additional external variables:

- „Statistics Learning Self Efficacy« - Similar to SPSS self efficacy, this variable can be defined as the students' belief in their own ability to perform well in statistics learning tasks. It is hypothesized that higher level of self efficacy increases the level of perceived usefulness as well as the level of perceived ease of use of SPSS.

- »Statistics Learning Value« - The value of statistics learning is to let the students acquire problem-solving competency, experience the inquiry activity, stimulate their own thinking, and find the relevance of statistics within daily life. If they can perceive these important values, they will be motivated to learn statistics. In our opinion the increase of statistics learning value decreases the level of statistics anxiety and increases the level of statistics learning self efficacy. Higher statistic learning value also increases the level of the perceived usefulness and the perceived ease of use of SPSS.

- "Satisfaction with Achievements« - As students increase their competence and achievement during 
learning statistics they feel satisfaction. This results in a higher level of the perceived usefulness and the perceived ease of use of SPSS.

The components of our TAM-based extended model are presented in Figure 2. Arrows in Figure 2 represent the dependencies between the model components, where signs $»+\ll$ and $\gg-\ll$ indicate the positive or the negative dependence, respectively. Regarding the model description, the following hypotheses are postulated:

- H1a: »SPSS Self Efficacy« has positive effect on $»$ Perceived Usefulness $\ll$.

- H1b: »SPSS Self Efficacy« has positive effect on »Perceived Ease of Use«.

- H2a: »Computer Attitude« has positive effect on $»$ Perceived Usefulness «.

- H2b: »Computer Attitude« has positive effect on »Perceived Ease of Use«.

- H3a: »Statistics Anxiety« has negative effect on »Perceived Usefulness «.

- H3b: »Statistics Anxiety« has negative effect on »Perceived Ease of Use«.
- H4a: »Statistics Learning Self Efficacy« has positive effect on »Perceived Usefulness «.

- H4b: »Statistics Learning Self Efficacy« has positive effect on »Perceived Ease of Use«.

- H5a: »Statistics Learning Value « has positive effect on $»$ Perceived Usefulness «.

- H5b: »Statistics Learning Value« has positive effect on $»$ Perceived Ease of Use «.

- H5c: »Statistics Learning Value« has positive effect on »Statistics Learning Self Efficacy«.

- H5d: »Statistics Learning Value« has negative effect on »Statistics Anxiety《.

- H6a: »Satisfaction with Achievements« has positive effect on »Perceived Usefulness«.

- H6b: «Satisfaction with Achievements« has positive effect on »Perceived Ease of Use«.

- H7: »Perceived Ease of Use « has positive effect on $»$ Perceived Usefulness $«$.

- H8: »Perceived Usefulness« has positive effect on »Behavioural Intentions to Use«.

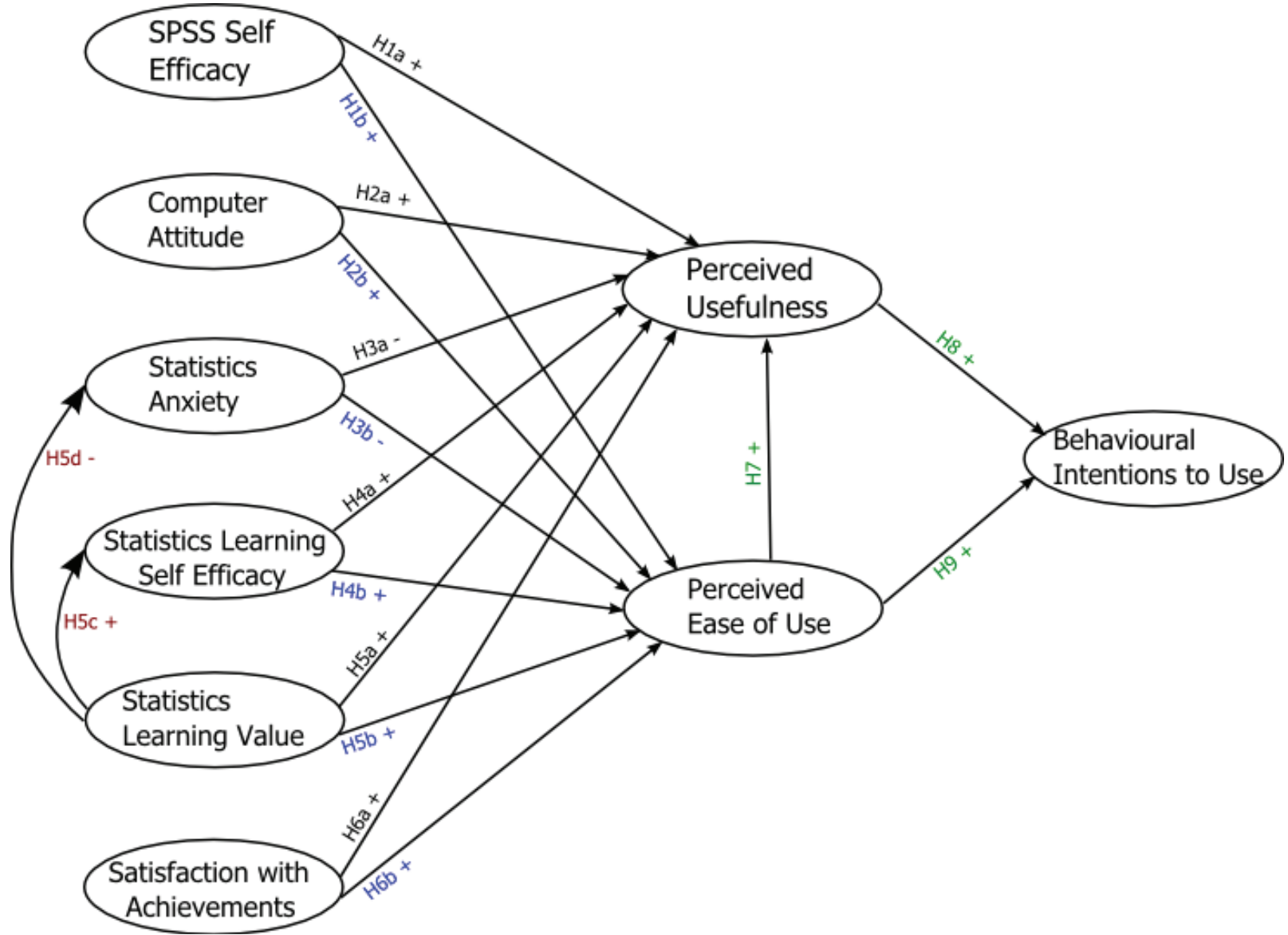

Figure 2: The extended TAM for analysing the acceptance of SPSS among the students of social sciences 
- H9: »Perceived Ease of Use« has positive effect on »Behavioural Intentions to Use«.

\section{Methodology}

\subsection{Instrumentation}

Our TAM-based extended model was tested on the university students of social sciences in Slovenia. For this purpose we prepared a questionnaire where every model component is described with a particular construct which is represented by several variables. In addition to the questionnaire given by Hsu et al. (2009) we considered also the questionnaire published in Tuan et al. (2005). The number of variables within a particular construct of our questionnaire is as follows (see Table 1):

- »Statistics Learning Self Efficacy« - 3 variables,

- »Behavioural Intentions to Use« and »Perceived Ease of Use« - 4 variables,

- »Perceived Usefulness«, »SPSS Self Efficacy«, "Computer Attitude«, »Statistics Learning Value« and »Satisfaction with Achievements « - 5 variables,

- »Statistics Anxiety《 - 7 variables.

All construct variables are measured on the 5-point Likert type scale of agreement, where 1 means »strongly disagree $\ll$, and 5 means »strongly agree $\ll$.

\subsection{Population, sample and data collection method}

The web survey was performed from June 2013 till February 2014. Seven faculties of three Slovenian universities collaborated:

- University of Ljubljana (Faculty of Administration, Faculty of Education, Faculty of Arts),

- University of Maribor (Faculty of Organizational Sciences, Faculty of Criminal Justice and Security, Faculty of Arts),

- University of Primorska (Faculty of Tourism Studies). The total number of completed questionnaires is 329 .

\subsection{Data analysis}

Data gathered from the survey were analysed in two stages. In the first stage the questionnaire used in the survey was evaluated. The reliability of the instrument was checked with Chrombach's $\alpha$ measure which was calculated for each questionnaire construct (i.e. model component). The sampling adequacy of the analysis was checked with the Kaiser-Meyer-Olkin measure and Bartlett's test of sphericity. Since our sample $(N=329)$ is big enough (Field, 2013), a confirmatory factor analysis for each construct was conducted. Furthermore, descriptive statistics of each construct were calculated.

In the second stage of data analysis the dependencies among the model components were studied using the regression analyses.

Before the analyses, we reversed scales of all three variables of the construct »Statistics Learning Self Efficacy « (which were negatively keyed in the original questionnaire).

\section{Results}

\subsection{Questionnaire evaluation and descriptive statistics}

The results of the first stage data analysis are presented in Table 1. In the first two columns the names of the constructs and the corresponding variables are listed. The third column of the table represents the number $N$ of respondents that answered all the questions within the particular construct. In the fourth column Chrombach's $\alpha$ is shown. The fifth column combines the first two eigenvalues together with the percentage of explained variance (EV), while in the sixth column the values of KMO and Bartlett's test are given. In the seventh column factor loadings are shown, and finally in the last column the average mean $\bar{x}$ and the average standard deviation (SD) for each construct are presented.

We can conclude from the results in Table 1 (columns from four up to seven) that our data reveals the same factors as proposed in our questionnaire.

It is evident from the last column of Table 1 that the highest rated construct is »Computer Attitude« with the highest av. mean 4,00 and the lowest av. standard deviation 0,63 . This shows that students are accustomed to working on computers, and are aware of computer usefulness and its importance nowadays.

Taking into account that all the questions of the construct »Statistics Anxiety《 were reverse phrased, it follows that the lowest rated construct is $\gg$ Behavioural Intentions to Use«, with av. mean slightly above three $(\bar{x}=3,05$ and SD $=0,99)$. On the other hand, the estimates of the construct »Perceived Usefulness « were much higher $(\bar{x}=3,66$ and $\mathrm{SD}=0,85)$. Results for these two constructs suggest that students actually are aware of the importance of SPSS and they find it quite useful for their job in the future, but at the moment they obviously have a lot of other priorities, and SPSS does not seem to be one of them.

Furthermore, the construct »Perceived Ease of Use« has the av. mean slightly above the intermediate value three $(\bar{x}=3,21$ and $\mathrm{SD}=0,89)$, which indicates that students are not very skilful at using SPSS. But on the other hand, from the values obtained for the construct »SPSS Self Efficacy« $(\bar{x}=3,75$ and $\mathrm{SD}=0,67)$, it is evident that students believe that they could complete a statistical analysis using SPSS, if 
Table 1: Results of the first stage data analysis

\begin{tabular}{|c|c|c|c|c|c|c|c|}
\hline $\begin{array}{l}\text { Factor / } \\
\text { Construct }\end{array}$ & Questions - Variables & $N$ & Chr. & $\begin{array}{c}\text { Eigenvalues, } \\
\text { Explained } \\
\text { Var. (EV) }\end{array}$ & $\begin{array}{l}\text { KMO, } \\
\text { Bartlett's } \\
\text { test }\end{array}$ & $\begin{array}{l}\text { Factor } \\
\text { Loadings }\end{array}$ & $\begin{array}{l}\text { Average } \\
\text { Mean, } \\
\text { SD }\end{array}$ \\
\hline \multirow{4}{*}{$\begin{array}{l}\text { Behavioural } \\
\text { Intentions } \\
\text { to Use }\end{array}$} & $\begin{array}{l}\text { I always try SPSS to conduct a task } \\
\text { whenever it has a feature to help me } \\
\text { perform it. }\end{array}$ & \multirow[t]{4}{*}{289} & \multirow[t]{4}{*}{0,73} & \multirow[t]{4}{*}{$\begin{array}{c}\lambda_{1}=2,62 \\
\lambda_{2}=0,79 \\
\mathrm{EV}=65,36 \%\end{array}$} & \multirow[t]{4}{*}{$\begin{array}{c}0,74 \\
p<0,0001\end{array}$} & 0,88 & \multirow[t]{4}{*}{$\begin{array}{l}\bar{x}=3,05 \\
\mathrm{SD}=0,99\end{array}$} \\
\hline & $\begin{array}{l}\text { I always try SPSS in as many cases/ } \\
\text { occasions as possible. }\end{array}$ & & & & & 0,91 & \\
\hline & $\begin{array}{l}\text { SPSS has lots of exciting functions } \\
\text { that I intend to use. }\end{array}$ & & & & & 0,84 & \\
\hline & $\begin{array}{l}\text { I intend to increase my use of SPSS } \\
\text { in the future. }\end{array}$ & & & & & 0,55 & \\
\hline \multirow{5}{*}{$\begin{array}{l}\text { Perceived } \\
\text { Usefulness }\end{array}$} & $\begin{array}{l}\text { SPSS use can improve my job per- } \\
\text { formance. }\end{array}$ & \multirow[t]{5}{*}{287} & \multirow[t]{5}{*}{0,90} & \multirow{5}{*}{$\begin{array}{c}\lambda_{1}=3,62 \\
\lambda_{2}=0,56 \\
\mathrm{EV}=72,36 \%\end{array}$} & \multirow[t]{5}{*}{$\begin{array}{c}0,87 \\
\mathrm{p}<0,0001\end{array}$} & 0,89 & \multirow[t]{5}{*}{$\begin{array}{l}\bar{x}=3,66 \\
\mathrm{SD}=0,85\end{array}$} \\
\hline & $\begin{array}{l}\text { SPSS use can make it easier to do } \\
\text { my job. }\end{array}$ & & & & & 0,91 & \\
\hline & $\begin{array}{l}\text { SPSS use in my job can increase my } \\
\text { productivity. }\end{array}$ & & & & & 0,88 & \\
\hline & I find SPSS useful in my job. & & & & & 0,82 & \\
\hline & $\begin{array}{l}\text { SPSS use would enable me to } \\
\text { accomplish statistical analysis more } \\
\text { quickly. }\end{array}$ & & & & & 0,74 & \\
\hline \multirow{4}{*}{$\begin{array}{l}\text { Perceived } \\
\text { Ease of Use }\end{array}$} & $\begin{array}{l}\text { I find it easy to get SPSS to do what } \\
\text { I want it to do. }\end{array}$ & \multirow[t]{4}{*}{290} & \multirow[t]{4}{*}{0,90} & \multirow{4}{*}{$\begin{array}{c}\lambda_{1}=3,06 \\
\lambda_{2}=0,37 \\
\mathrm{EV}=76,56 \%\end{array}$} & \multirow[t]{4}{*}{$\begin{array}{c}0,84 \\
\mathrm{p}<0,0001\end{array}$} & & \multirow[t]{4}{*}{$\begin{array}{l}\bar{x}=3,21 \\
\mathrm{SD}=0,89\end{array}$} \\
\hline & $\begin{array}{l}\text { My interaction with SPSS is under- } \\
\text { standable and clear. }\end{array}$ & & & & & 0,91 & \\
\hline & $\begin{array}{l}\text { I find SPSS to be flexible to interact } \\
\text { with. }\end{array}$ & & & & & 0,88 & \\
\hline & $\begin{array}{l}\text { It is easy for me to become skilful at } \\
\text { using SPSS. }\end{array}$ & & & & & 0,86 & \\
\hline \multirow{6}{*}{$\begin{array}{l}\text { SPSS } \\
\text { Self Efficacy }\end{array}$} & $\begin{array}{l}\text { I could complete a statistical analy- } \\
\text { sis using SPSS ... }\end{array}$ & \multirow[t]{6}{*}{291} & \multirow[t]{6}{*}{0,81} & \multirow{6}{*}{$\begin{aligned} \lambda_{1} & =2,99 \\
\lambda_{2} & =0,80 \\
\mathrm{EV} & =59,78 \%\end{aligned}$} & \multirow[t]{6}{*}{$\begin{array}{c}0,80 \\
p<0,0001\end{array}$} & & \multirow[t]{6}{*}{$\begin{array}{l}\bar{x}=3,79 \\
\mathrm{SD}=0,67\end{array}$} \\
\hline & $\begin{array}{l}\ldots \text { if I had seen someone else using } \\
\text { SPSS before trying it myself. }\end{array}$ & & & & & 0,67 & \\
\hline & $\begin{array}{l}\text {... if someone else had helped me } \\
\text { get started. }\end{array}$ & & & & & 0,87 & \\
\hline & $\begin{array}{l}\text {...if someone showed me how to do } \\
\text { it first. }\end{array}$ & & & & & 0,86 & \\
\hline & $\begin{array}{l}\ldots \text { if I could call someone for help if } \\
\text { I got stuck. }\end{array}$ & & & & & 0,83 & \\
\hline & $\begin{array}{l}\text {... if I had used similar software } \\
\text { before this one to do the same job. }\end{array}$ & & & & & 0,59 & \\
\hline
\end{tabular}


Table 1: Results of the first stage data analysis (continued)

\begin{tabular}{|c|c|c|c|c|c|c|c|}
\hline $\begin{array}{l}\text { Factor / } \\
\text { Construct }\end{array}$ & Questions - Variables & $N$ & $\begin{array}{c}\text { Chr. } \\
\alpha\end{array}$ & $\begin{array}{l}\text { Eigenvalues, } \\
\text { Explained } \\
\text { Var. (EV) }\end{array}$ & $\begin{array}{l}\text { KMO, } \\
\text { Bartlett's } \\
\text { test }\end{array}$ & $\begin{array}{c}\text { Factor } \\
\text { Loadings }\end{array}$ & $\begin{array}{l}\text { Average } \\
\text { Mean, } \\
\text { SD }\end{array}$ \\
\hline \multirow{5}{*}{$\begin{array}{l}\text { Computer } \\
\text { Attitude }\end{array}$} & $\begin{array}{l}\text { Computers are bringing us into a } \\
\text { bright new era. }\end{array}$ & \multirow[t]{5}{*}{298} & \multirow[t]{5}{*}{0,83} & \multirow{5}{*}{$\begin{array}{c}\lambda_{1}=3,00 \\
\lambda_{2}=0,69 \\
E V=59,91 \%\end{array}$} & \multirow[t]{5}{*}{$\begin{array}{c}0,83 \\
\mathrm{p}<0,0001\end{array}$} & 0,81 & \multirow[t]{5}{*}{$\begin{array}{l}\bar{x}=4,00 \\
\mathrm{SD}=0,63\end{array}$} \\
\hline & $\begin{array}{l}\text { The use of computers is enhancing } \\
\text { our standard of living. }\end{array}$ & & & & & 0,82 & \\
\hline & $\begin{array}{l}\text { There are unlimited possibilities of } \\
\text { computer applications that haven't } \\
\text { even been thought of yet. }\end{array}$ & & & & & 0,73 & \\
\hline & $\begin{array}{l}\text { Computers are responsible for many } \\
\text { of the good things we enjoy. }\end{array}$ & & & & & 0,77 & \\
\hline & $\begin{array}{l}\text { Working with computers is an } \\
\text { enjoyable experience. }\end{array}$ & & & & & 0,73 & \\
\hline \multirow{7}{*}{$\begin{array}{l}\text { Statistics } \\
\text { Anxiety }\end{array}$} & $\begin{array}{l}\text { I wonder why I have to do all these } \\
\text { things in statistics when in actual } \\
\text { life I'll never use them. }\end{array}$ & \multirow[t]{7}{*}{299} & \multirow[t]{7}{*}{0,92} & \multirow[t]{7}{*}{$\begin{aligned} \lambda_{1} & =4,76 \\
\lambda_{2} & =0,64 \\
\mathrm{EV} & =68,01 \%\end{aligned}$} & \multirow[t]{7}{*}{$\begin{array}{c}0,92 \\
p<0,0001\end{array}$} & 0,82 & \multirow[t]{7}{*}{$\begin{array}{l}\bar{x}=2,27 \\
\mathrm{SD}=0,82\end{array}$} \\
\hline & $\begin{array}{l}\text { Statistics is worthless to me since } \\
\text { it's empirical and my area of spe- } \\
\text { cialization is philosophical. }\end{array}$ & & & & & 0,82 & \\
\hline & I feel statistics is a waste of time. & & & & & 0,87 & \\
\hline & $\begin{array}{l}\text { I don't want to learn to like statis- } \\
\text { tics. }\end{array}$ & & & & & 0,73 & \\
\hline & $\begin{array}{l}\text { I wish the statistics requirement } \\
\text { would be removed from my aca- } \\
\text { demic program. }\end{array}$ & & & & & 0,84 & \\
\hline & $\begin{array}{l}\text { I don't understand why somebody in } \\
\text { my field needs statistics. }\end{array}$ & & & & & 0,83 & \\
\hline & $\begin{array}{l}\text { I don't see why I have to clutter up } \\
\text { my head with statistics. It has no } \\
\text { significance to my life work. }\end{array}$ & & & & & 0,87 & \\
\hline \multirow{3}{*}{$\begin{array}{l}\text { Learning } \\
\text { Statistics } \\
\text { Self Efficacy }\end{array}$} & $\begin{array}{l}\text { No matter how much effort I put in, } \\
\text { I cannot learn statistics. (R) }\end{array}$ & \multirow[t]{3}{*}{307} & \multirow[t]{3}{*}{0,69} & \multirow{3}{*}{$\begin{aligned} \lambda_{1} & =2,18 \\
\lambda_{2} & =0,50 \\
\mathrm{EV} & =72,56 \%\end{aligned}$} & \multirow[t]{3}{*}{$\begin{array}{c}0,69 \\
\mathrm{p}<0,0001\end{array}$} & 0,81 & \multirow[t]{3}{*}{$\begin{array}{l}\bar{x}=3,69 \\
\mathrm{SD}=0,86\end{array}$} \\
\hline & $\begin{array}{l}\text { When statistics activities are too dif- } \\
\text { ficult, I give up or only do the easy } \\
\text { parts. (R) }\end{array}$ & & & & & 0,89 & \\
\hline & $\begin{array}{l}\text { When I find the statistics content } \\
\text { difficult, I do not try to learn it. (R) }\end{array}$ & & & & & 0,86 & \\
\hline
\end{tabular}


Table 1: Results of the first stage data analysis (continued)

\begin{tabular}{|c|c|c|c|c|c|c|c|}
\hline $\begin{array}{l}\text { Factor / } \\
\text { Construct }\end{array}$ & Questions - Variables & $N$ & $\begin{array}{c}\text { Chr. } \\
\alpha\end{array}$ & $\begin{array}{c}\text { Eigenvalues, } \\
\text { Explained } \\
\text { Var. (EV) } \\
\end{array}$ & $\begin{array}{l}\text { KMO, } \\
\text { Bartlett's } \\
\text { test }\end{array}$ & $\begin{array}{l}\text { Factor } \\
\text { Loadings }\end{array}$ & $\begin{array}{l}\text { Average } \\
\text { Mean, } \\
\text { SD }\end{array}$ \\
\hline \multirow{5}{*}{$\begin{array}{l}\text { Statistics } \\
\text { Learning } \\
\text { Value }\end{array}$} & $\begin{array}{l}\text { I think that learning statistics is } \\
\text { important because I can use it in my } \\
\text { daily life. }\end{array}$ & \multirow[t]{5}{*}{311} & \multirow[t]{5}{*}{0,77} & \multirow[t]{5}{*}{$\begin{aligned} \lambda_{1} & =2,63 \\
\lambda_{2} & =0,71 \\
\mathrm{EV} & =52,68 \%\end{aligned}$} & \multirow[t]{5}{*}{$\begin{array}{c}0,82 \\
\mathrm{p}<0,0001\end{array}$} & 0,734 & \multirow[t]{5}{*}{$\begin{array}{l}\bar{x}=3,20 \\
\mathrm{SD}=0,71\end{array}$} \\
\hline & $\begin{array}{l}\text { I think that learning statistics is } \\
\text { important because it stimulates my } \\
\text { thinking. }\end{array}$ & & & & & 0,746 & \\
\hline & $\begin{array}{l}\text { In statistics, I think that it is impor- } \\
\text { tant to learn to solve problems. }\end{array}$ & & & & & 0,730 & \\
\hline & $\begin{array}{l}\text { In statistics, I think it is important to } \\
\text { participate in inquiry activities. }\end{array}$ & & & & & 0,665 & \\
\hline & $\begin{array}{l}\text { It is important to have the opportuni- } \\
\text { ty to satisfy my own curiosity when } \\
\text { learning statistics. }\end{array}$ & & & & & 0,751 & \\
\hline \multirow{5}{*}{$\begin{array}{l}\text { Satisfaction } \\
\text { with } \\
\text { Achievements }\end{array}$} & $\begin{array}{l}\text { During a statistics course, I feel } \\
\text { most fulfilled when I attain a good } \\
\text { score in a test. }\end{array}$ & \multirow[t]{5}{*}{308} & \multirow[t]{5}{*}{0,77} & \multirow[t]{5}{*}{$\begin{aligned} \lambda_{1} & =2,73 \\
\lambda_{2} & =0,97 \\
\mathrm{EV} & =54,55 \%\end{aligned}$} & \multirow[t]{5}{*}{$\begin{array}{c}0,72 \\
p<0,0001\end{array}$} & 0,643 & \multirow[t]{5}{*}{$\begin{array}{l}\bar{x}=3,94 \\
\mathrm{SD}=0,66\end{array}$} \\
\hline & $\begin{array}{l}\text { I feel most fulfilled when I feel } \\
\text { confident about the content in a sta- } \\
\text { tistics course. }\end{array}$ & & & & & 0,763 & \\
\hline & $\begin{array}{l}\text { During a statistics course, I feel } \\
\text { most fulfilled when I am able to } \\
\text { solve a difficult problem. }\end{array}$ & & & & & 0,725 & \\
\hline & $\begin{array}{l}\text { During a statistics course, I feel } \\
\text { most fulfilled when the teacher } \\
\text { accepts my ideas. }\end{array}$ & & & & & 0,788 & \\
\hline & $\begin{array}{l}\text { During a statistics course, I feel } \\
\text { most fulfilled when other students } \\
\text { accept my ideas. }\end{array}$ & & & & & 0,764 & \\
\hline
\end{tabular}

they had appropriate support and enough experiences. This holds true especially for the second degree students $(\bar{x}=3,94$ and $\mathrm{SD}=0,65$ ).

For the construct "Statistics Anxiety« we obtained $\bar{x}=2,27$ and $\mathrm{SD}=0,82$. These values mean that students are not too anxious about statistics, although we would like the values to be even lower. Similarly, the construct »Statistics Learning Value « has the av. mean slightly above the intermediate value three $(\bar{x}=3,20$ and $\mathrm{SD}=0,71)$, indicating that an average student is not aware in what way statistics can contribute to his everyday activities and critical thinking.

The results for the construct »Satisfaction with Achievements ( $(\bar{x}=3,94$ and $\mathrm{SD}=0,66)$ mean that students are quite satisfied when they achieve some good results regarding statistics.
For the last construct »Statistics Learning Self Efficacy « we obtained $\bar{x}=3,69$ and $\mathrm{SD}=0,86$. Taking into account that we analyzed the recoded variables of this construct, these values indicate that learning statistics is not very easy for students, but it does not cause an insurmountable obstacle for them either.

\subsection{Regression analysis}

In the second stage of data analysis the regression analysis was performed. The unstandardized regression coefficients indicating dependencies among the model components are presented in Figure 3. 


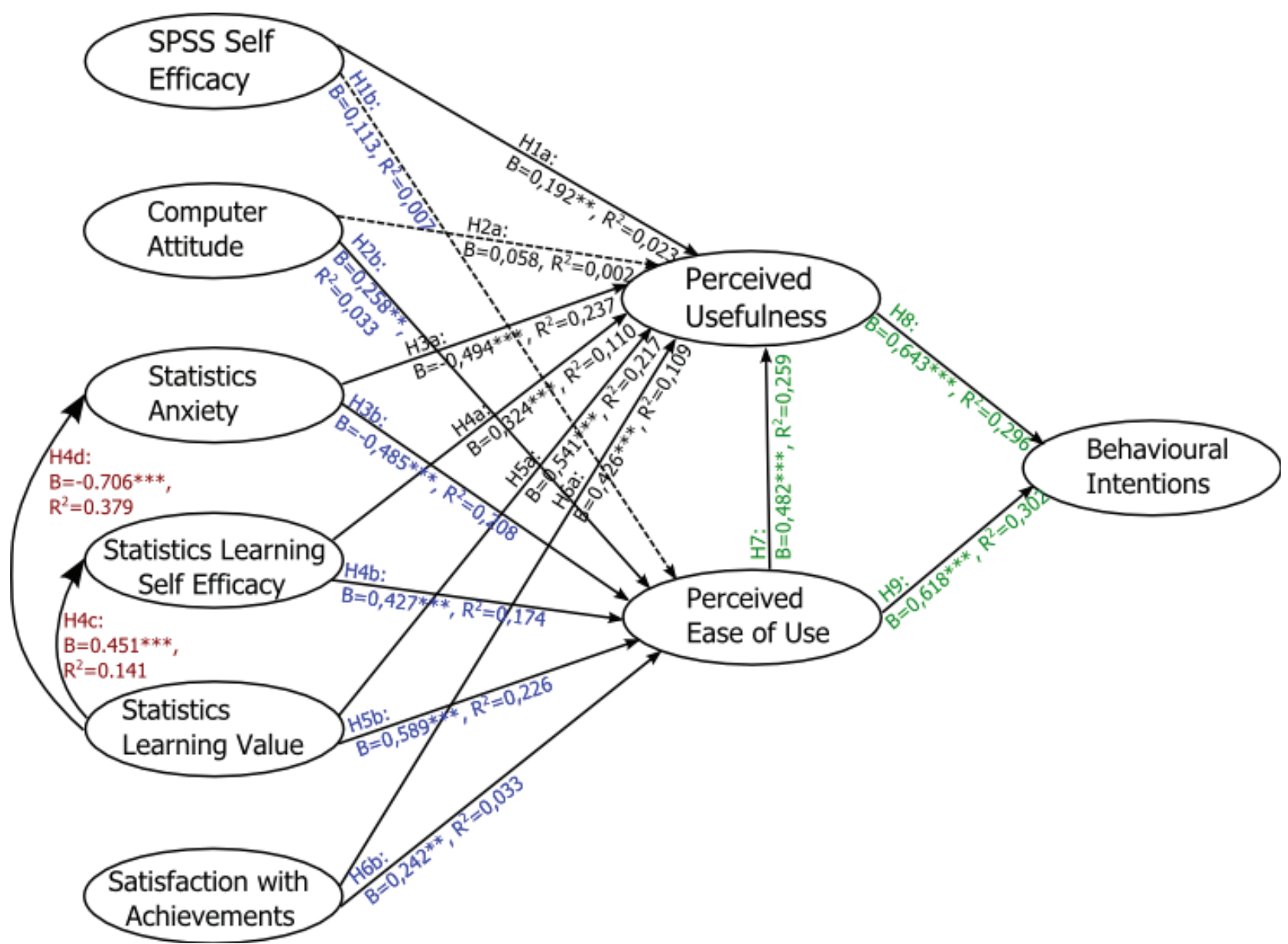

Statistical significance of unstandardized regression coefficients:

* denotes 5\% statistical significance level

** denotes $1 \%$ statistical significance level

*** denotes $0,1 \%$ statistical significance level

Figure 3: Unstandardized regression coefficients of model components

We can see from Figure 3 that all predicted dependencies between nine model components are statistically significant at 5\% significance level, except the dependence of »Perceived Ease of Use« on »SPSS Self Efficacy« $(B=0,113$, $\left.\mathrm{R}^{2}=0,007\right)$ and »Perceived Usefulness « on »Computer Attitude « $\left(B=0,058, R^{2}=0,002\right)$, where the percentages of explained variances in both regressions are low and the unstandardized regression coefficients are not statistically different from zero at 5\% significance level. Therefore, the hypotheses H1b and H2a could not be confirmed.

The »SPSS Self Efficacy« has a positive effect on »Perceived Usefulness « $\left(\mathrm{B}=0,192, \mathrm{R}^{2}=0,023\right)$ at $5 \%$ significance level which confirms our first hypothesis H1a. The »Computer Attitude« has positive effect on »Perceived
Ease of Use « $\left(B=0,258, R^{2}=0,033\right)$ at $1 \%$ significance level which confirms the hypothesis $\mathrm{H} 2 \mathrm{~b}$.

In the questionnaire the negatively stated items for »Statistics Anxiety« were used which means that higher scores represent higher level of statistics anxiety. Therefore, we assumed that there exists a negative effect on both $»$ Perceived Usefulness « (H3a) and »Perceived Ease of Use« (H3b). The results confirmed our expectations since both unstandardized regression coefficients are negative and statistically significant at $0.1 \%$ significant level, while $\mathrm{B}=-0,494\left(\mathrm{R}^{2}=0,237\right)$ for the »Perceived Usefulness « and $B=-0,485\left(R^{2}=0,208\right)$ for the »Perceived Ease of Use $«$.

The »Statistics Learning Self Efficacy« has a positive effect on the »Perceived Usefulness $«\left(B=0,324, R^{2}=0,110\right)$ 
and the »Perceived Ease of Use « $\left(B=0,427, R^{2}=0,174\right)$ at $0.1 \%$ significance level. Therefore, our hypotheses $\mathrm{H} 4 \mathrm{a}$ and $\mathrm{H} 4 \mathrm{~b}$ could be confirmed.

About »Statistics Learning Value« four hypotheses were postulated (see Figure 2). All of them can be confirmed. Namely, the "Statistics Learning Value« has a positive effect on the $»$ Perceived Usefulness $«\left(B=0,541, R^{2}=0,217\right)$, the $»$ Perceived Ease of Use $«\left(B=0,589, R^{2}=0,226\right)$, and the »Statistics Learning Self Efficacy« $\left(\mathrm{B}=0,451, \mathrm{R}^{2}=0,141\right)$, and a negative effect on the »Statistics Anxiety $(\mathrm{B}=-0,706$, $\mathrm{R}^{2}=0,379$ ). Therefore, all four hypotheses H5a, H5b, H5c, and $\mathrm{H} 5 \mathrm{~d}$ can be confirmed at $0,1 \%$ significance level.

The hypotheses H6a and H6b explore the effects of the »Satisfaction with Achievements« on both the »Perceived Usefulness « and the »Perceived Ease of Use«. Both regressions reveal positive effects of the "Satisfaction with Achievements« on two dependent variables. More precisely, the unstandardized regression coefficient for the $»$ Perceived Usefulness « is equal to $B=0,426 \quad\left(R^{2}=0,109\right)$, and the unstandardized regression coefficient for the »Perceived Ease of Use « is equal to $B=0,242\left(R^{2}=0,033\right)$. Since both reported regression coefficients are positive and statistically significantly different from zero at $1 \%$ significant level, both hypotheses H6a and H6b can be confirmed.

The hypothesis $\mathrm{H} 7$ stated that »Perceived Ease of Use« has a positive effect on »Perceived Usefulness « can also be confirmed while the unstandardized regression coefficients is positive $\left(B=0,482, R^{2}=0,259\right)$ and statistically significantly different from zero at $0,1 \%$ significance level.

Two of the highest three proportions of explained variance were obtained in two linear regression models with the $»$ Behavioural Intentions to Use « as a dependent variable. To be precise, »Perceived Usefulness « $(\mathrm{B}=0,643)$ can explain $29,6 \%$ of variance of the »Behavioural Intentions to Use«, while the »Perceived Ease of Use $«(B=0,618)$ can explain $30,2 \%$ variance of the »Behavioural Intentions to Use According to positive unstandardized regression coefficients in both regressions, hypotheses $\mathrm{H} 8$ and $\mathrm{H} 9$ can be confirmed.

\section{Discussion}

The first objective of our paper was to identify the external factors which may influence the adoption and continuous utilization of the SPSS among the university students of social sciences. We defined six potential factors $(»$ SPSS Self Efficacy«, »Computer Attitude«, »Statistics Anxiety«, »Statistics Learning Self Efficacy«, »Statistics Learning Value« and »Satisfaction with Achievements «) which represent the external variables of our extended TAM. Since all these variables are found to have a direct influence on the »Perceived Usefulness « and/or »Perceived Ease of Use«, we can assert that they also affect the behavioural intentions to use SPSS. Therefore, all these variables are relevant to be involved in analysing the adoption of SPSS among the students of social sciences.

The second objective was to examine the relationships among the model components. The results of our empirical study show that all three conventional relationships, usually formulated in TAM applications, can be confirmed. Namely, our results prove that both key components of the TAM, »Perceived Usefulness « and »Perceived Ease of Use« positively influence students' behavioural intentions to use SPSS, while »Perceived Usefulness« is also positively affected by »Perceived Ease of Use«. In our opinion these results prove the applicability of TAM to our topic.

Since four of six external variables of our model are the same as the external variables considered by Hsu et al. (2009) it is interesting to compare the results of both studies.

In our study we found out that »SPSS Self Efficacy» has a positive effect only on »Perceived Usefulness«, while the effect of this model component on »Perceived Ease of Use« is not significant. These statements agree with the findings of Hsu et al. (2009).

However, our results show that »Computer Attitude« has a positive influence on "Perceived Ease of Use«, while the effect of this model component on $»$ Perceived Usefulness « is not significant. It is interesting that the results of Hsu et al. (2009) are just the opposite.

As we expected, it was found that »Statistics Anxiety « has a direct negative impact on both, »Perceived Usefulness « and »Perceived Ease of Use«. This reflects in a negative influence on students' behavioural intentions to use SPSS. The results of Hsu et al. (2009) are similar. We agree with the authors that educators should try to eliminate students' anxiety toward using SPSS by introducing a few carefully designed activities and by presenting real-world examples. In order to effectively reduce students' anxiety in learning statistics, Pan and Tang (2004) recommended the combination of application oriented teaching methods and instructors' attentiveness to students' anxiety. The results of our study also indicate that statistics anxiety can be mitigated by increasing the value of statistics learning.

There are some limitations that should be taken into consideration in the future research. For example, future research may examine whether demographic variables such as gender, age, educational level, etc. could potentially confound the observed relationships. As previous researches suggest that the TAM and the end-user technology usage may differ across the cultural borders (Hsu et al., 2009), a reasonable next step would be to extent this research to other countries.

\section{Conclusion}

In the paper, an extended Technology Acceptance Model (TAM) for analysing the acceptance of IBM SPSS Statistics among the university students of social sciences was deve- 
loped. On top of the traditional components of the TAM, the following six external variables were included: »SPSS Self Efficacy«, »Computer Attitude «, »Statistics Anxiety«, »Statistics Learning Self Efficacy«, »Statistics Learning Value« and »Satisfaction with Achievements $«$. The model was tested using the web survey involving the university students of social sciences from seven different faculties at three Slovenian universities.

The questionnaire used in the survey was evaluated with a confirmatory factor analysis. The reliability of the scale with Chrombach's $\alpha$ was examined. The sampling adequacy for the analysis with the Kaiser-Meyer-Olkin measure and Bartlett's test of sphericity was checked. Descriptive statistics of the model components were calculated, and dependencies between the model components were studied using the regression analyses.

The empirical results prove that all external variables considered in our model are relevant, and directly influence the »Perceived Usefulness « and »Perceived Ease of Use« which are the key components of the traditional TAM. Both, »Perceived Usefulness « and »Perceived Ease of Use« have direct impact on the students' behavioural intention which affects their actual use of SPSS in the future. Therefore, we can assert that all external variables included in our model represent the potential areas where activities to reduce the students' anxiety and to strengthen the positive attitudes towards statistics and SPSS can be planned.

Therefore, we can conclude that the aim of the paper has been achieved. Our TAM-based extended model is found to be useful in studying the adoption and continuous utilization of SPSS among the students of social sciences. Findings obtained with the model application are of great value for educators, and can help them to improve the learning process.

In the next stage of our research we are going to continue the validation of our model by expanding the survey to some faculties from other East European countries covering the social science studying programs. In addition to regression analyses we intend to employ other applicable statistical methods. For example, structural equation modelling which could enable us to investigate all causal connections among the model components simultaneously, or hierarchical clustering combined with K-means clustering which may reveal clusters of students with similar attitudes toward statistics and SPSS.

\section{References}

Al-Adwan, Am., Al-Adwan, Ah., \& Smedley, J. (2013). Exploring students acceptance of e-learning using Technology Acceptance, Model in Jordanian universities. International Journal of Education and Development using Information and Communication Technology, (IJEDICT), 9(2), 4-18. Retrieved December 5, 2013 from http://ijedict.dec.uwi.edu/ viewissue.php?id=35
Baloğlu, M. (2003). Individual differences in statistics anxiety among college students. Personality and Individual Differences, 34(5), 855-865, http://dx.doi.org/10.1016/ S0191-8869(02)00076-4

Bisoux, T. (2002). The e-learning equation. BizEd, 40-45.

Chuttur M.Y. (2009). Overview of the Technology Acceptance Model: Origins, Developments and Future Directions. Working Papers on Information Systems, 9(37), 9-37. Retrieved October 12, 2013 from http://sprouts.aisnet. org/785/1/TAMReview.pdf

Davis, F. D. (1986). A technology acceptance model for empirically testing new end-user information systems: theory and results. Ph.D. Thesis, Massachusetts Institute of Technology, Sloan School of Management.

Davis, F. D. (1989). Perceived Usefulness, Perceived Ease of Use, and User Acceptance of Information Technology. MIS Quarterly, 13(3), 319-340, http://dx.doi.org/10.2307/249008

DeWayne, T. A. (2010). Anxiety and Attitude of Graduate Students in On-Campus vs. Online Statistics Courses. Journal of Statistics Education, 18(1), 1-15. Retrieved October 12, 2013 from http://www.amstat.org/publications/jse/v18n1/derryberry.pdf

Escobar-Rodriguez, T., \& Monge-Lozano, P. (2012). The acceptance of Moodle technology by business administration students. Computers \& Education, 58, 1085-1093, http://dx.doi. org/10.1016/j.compedu.2011.11.012

Field, A. (2013). Discovering statistics using IBM SPSS statistics. London: SAGE.

Hsu M. K., Wang S. W., \& Chiu K. K. (2009). Computer attitude, statistics anxiety and self-efficacy on statistical software adoption behavior: An empirical study of online MBA learners. Computers in Human Behavior, 25, 412-420, http:// dx.doi.org/10.1016/j.chb.2008.10.003

IBM (2010). Making statistics relevant and easy to learn. Retrieved October 13, 2013, from http://www.presidion.com/industry solutions/academia/materials/case_studies/YTC03045USEN. pdf

Kljajić, M. et al. (2012). System approach to MIS and DSS and its modeling within SD, In M. Mora, O. Gelman, A. Steenkamp, \& M. Raisinghani (Eds.) Research Methodologies, Innovations and Philosophies in Software Systems Engineering and Information Systems (340-359). Hershey, Information Science Reference, http://dx.doi.org/10.4018/978-1-4666-0179-6. ch017

Lee, D.Y., \& Lehto, M.R. (2013). User acceptance of YouTube for procedural learning: An extension of the Technology Acceptance Model. Computers \& Education, 61, 193-208, http://dx.doi.org/10.1016/j.compedu.2012.10.001

Legris, P., Inghamb, J., \& Collerettec, P. (2003). Why do people use information technology? A critical review of the technology acceptance model. Information \& Management, 40, 191-204, http://dx.doi.org/10.1016/S0378-7206(01)00143-4

Liu, I-F. et al. (2010). Extending the TAM model to explore the factors that affect Intention to Use an Online Learning Community. Computers \& Education, 54 (2), 600-610, http:// dx.doi.org/10.1016/j.compedu.2009.09.009

Onwuegbuzie, A. J. (2004). Academic procrastination and statistics anxiety. Assessment \& Evaluation in Higher Education, 29(1), 3-19, http://dx.doi.org/10.1080/0260293042000160384

Onwuegbuzie, A.J., \& Wilson, V.A. (2003). Statistics anxiety: Nature, etiology, antecedents, effects, and treatments - A 
comprehensive review of the literature. Teaching in Higher Education, 8 (2), 195-209, http://dx.doi.org/10.1080/135625 1032000052447

Padilla-Meléndez, A., Del Aguila-Obra, A.R., \& Garrido-Moreno, A. (2013). Perceived playfulness, gender differences and technology acceptance model in a blended learning scenario. Computers \& Education, 63, 306-317, http://dx.doi. org/10.1016/j.compedu.2012.12.014

Pan, W., \& Tang, M. (2004). Examining the Effectiveness of Innovative Instructional Methods on Reducing Statistics Anxiety for Graduate Students in the Social Sciences. Journal of Instructional Psychology, 31(2), 149-159.

Ravid, R., \& Leon, M. R. (1995). Students' perceptions of the research component in master's level teacher education programs. Paper presented at the Annual Meeting of the American Educational Research Association. San Francisco, CA, April 18-22, 1995. (ERIC Document Reproduction Service No. ED393840).

Shah, S. A. M. et al. (2013). Employee Behavior Towards Adoption of E-learning Courses: Validating Technology Acceptance Model. Mediterranean Journal of Social Sciences, 4(14), 765 773, http://dx.doi.org/10.5901/mjss.2013.v4n14p765

Sharma, S. K., \& Chandel, J. K. (2013). Technology Acceptance Model for the Use of Learning Through Websites Among Students in Oman. The International Arab Journal of Information Technology, 3(1), 44-49.

Shroff, R. H., Deneen, C. C., \& Ng, E. M. W. (2011). Analysis of the technology acceptance model in examining students' behavioural intention to use an e-portfolio system. Australasian Journal of Educational Technology, 27(4), 600618. Retrieved December 12, 2013 from http://www.ascilite. org.au/ajet/ajet27/shroff.html

Stickels, J.W., \& Dobbs, R.R. (2007). Helping Alleviate Statistical Anxiety with Computer Aided Statistical Classes. The Journal of Scholarship of Teaching and Learning, 7(1), 1-15, Retrieved October 12, 2013 from http://josotl.indiana.edu/ article/view/1676/1674

Tabak, F., \& Nguyen, N. T. (2013). Technology Acceptance and Performance in Online Learning Environments: Impact of Self-Regulation. MERLOT Journal of Online Learning and Teaching, 9(1), 1-11. Retrieved December 2, 2013 from http:// jolt.merlot.org/vol9no1/tabak_0313.pdf

Teo, T. (2009). Modelling technology acceptance in education: A study of pre-service teachers. Computers \& Education, 52, 302-312, http://dx.doi.org/10.1016/j.compedu.2008.08.006

Teo, T. (2010). An empirical study to validate the Technology Acceptance Model (TAM) in explaining the intention to use technology among educational users. International Journal of Information and Communication Technology Education, 6(4), 1-12, http://dx.doi.org/10.4018/jicte.2010100101

Teo, T. (2011a). Factors influencing teachers' intention to use technology: Model development and test. Computers \& Education, (57), 2432-2440, http://dx.doi.org/10.1016/j.compedu.2011.06.008
Teo, T. (2011b). Technology Acceptance in Education, Research and Issues. Rotterdam: Sense Publishers.

Tuan H. L., Chin C. C., \& Shieh S. H. (2005). The development of a questionnaire to measure students ${ }^{6}$ motivation towards science learning. International Journal of Science Education, 27(6), 639-654, http://dx.doi.org/10.1080/09500690420003 23737

Yousafzai, S.Y, etal.(2007). Technology acceptance: a meta-analysis of the TAM: Part 1. Journal of Modelling in Management, 2(3), 251 - 280, http://dx.doi.org/10.1108/17465660710834453

Wang, W. T., \& Liu, C. Y. (2005). The Application of the Technology Acceptance Model: A New Way to Evaluate Information System Success. In J. D. Sterman (ed.), N. P. Repenning (ed.), R. S. Langer (ed.), J. I. Rowe (ed.), \& J. M. Yanni (ed.) Proceedings of the 23th International Conference of the System Dynamics Society. Albany: System Dynamics Society.

Zeidner, M. (1991). Statistics and mathematics anxiety in social science students: Some interesting parallels. British Journal of Educational Psychology, 61(3), 319-328, http://dx.doi. org/10.1111/j.2044-8279.1991.tb00989.x

\section{Acknowledgment}

Authors express their thanks to Jasna Mažgon, Lan Umek and Janez Vogrinc from the University of Ljubljana, Matevž Bren, Janja Jerebic and Jerneja Šifrer from the University of Maribor, Daša Fabjan and Saša Planic from the University of Primorska, who encourage their students to participate in the survey.

Alenka Brezavšček is an Assistant Professor of Stochastic Processes at the Faculty of Organizational Sciences, University of Maribor. Her main research interests are stochastic processes, system reliability and availability, and information system security.

Petra Šparl is an Associate Professor of Mathematics at the Faculty of Organizational Sciences, University of Maribor, Slovenia. Her main research interests are graph theory, data analysis and students' performance in methodological courses.

Anja Žnidaršč is an Assistant Professor of Quantitative Methods at the Faculty of Organizational Sciences, University of Maribor, Slovenia. Her main research interests are social network analysis, micro-enterprises and information-communication technology, and students performance in methodological courses. 